\title{
Agricultural Productivity, Poverty Reduction and Inclusive Growth in Africa: Linkages and Pathways
}

\author{
Adeyemi A. Ogundipe ${ }^{1 *}$, Emmanuel A. Oduntan ${ }^{1}$, Adebayo I. Ogunniyi ${ }^{2}$ \\ and Kehinde O. Olagunju ${ }^{3}$ \\ ${ }^{1}$ Department of Economics and Development Studies, Covenant University, Ota, Ogun State, Nigeria. \\ ${ }^{2}$ Department of Agricultural Economics, University of Ibadan, Nigeria. \\ ${ }^{3}$ Institute of Regional Economics and Rural Development, Szent Istvan University, Gödöllö, Hungary.
}

\section{Authors' contributions}

This work was carried out in collaboration among all authors. Author AAO designed the study, performed the econometric analysis, wrote the results, discussion and the first draft of the manuscript. Authors EAO and AIO managed the analysis of the conceptual framework. Author KOO managed the literature searches. All authors read and approved the final manuscript.

Article Information

DOI: $10.9734 / A J A E E S / 2017 / 32427$

Editor(s):

(1) Wang Guangjun, Pearl River Fisheries Research Institute, Chinese Academy of Fishery Sciences, China.

Reviewers:

(1) Ekenta, Cornelius Michael, Ahmadu Bello University, Zaria, Nigeria.

(2) O. Murat Kocturk, Celal Bayar University, Manisa, Turkey.

Complete Peer review History: http://www.sciencedomain.org/review-history/19773

Original Research Article

Received $25^{\text {th }}$ February 2017

Accepted $20^{\text {th }}$ May 2017

Published $30^{\text {th }}$ June 2017

\begin{abstract}
Poverty in Africa is primarily rural concentrated, about $75 \%$ of the poor population live in rural areas and draws their livelihood and food from agriculture. The Sub-Saharan African region is home to more than quarter of a billion people living in extreme poverty, with the Eastern and Southern Africa having the world's highest concentrations of poor people. The renewed focus on the poverty reducing potential of agricultural productivity accentuate from the fact that the incidence of poverty in Sub-Saharan Africa is increasing faster than the population. The study examined the effect of agricultural productivity on poverty reduction in Africa using the dynamic panel data approach estimated using the System-GMM technique for the period 1991-2015. The conceptual framework of the study identified three main linkages via which agricultural productivity translates to poverty reduction; this include: $i$. income empowerment, ii. Market expansion, and iii. Sustenance enhancement. The empirical result suggests that agricultural value added per worker contributes
\end{abstract}


significantly to reducing rural poverty in Africa. On the other hand, food production index and GDP per capita were more important factors in curbing urban and dollar poverty implying that non-farm poor tends to have a large food marginal propensity to consume (MPC). The insignificance of GDP per capita in dwindling rural poverty reflects that the reality that growth in other sector does not influence the livelihood of the rural poor farmers due to its subsistence nature. Finally, domestic credit to private sectors and institutions were significant in reducing all categories of poverty, with largest impact on rural poverty. It implies that development programmes targeted at enhancing agricultural productivity should encompass strategies for accessing credit in order to boost the asset base of rural farmer for a large scale commercial production. Also, appropriate macroeconomic policies and institutional quality needs to be enhanced to boost provision of social services, equitable land and credit access.

Keywords: Agricultural productivity; poverty, inclusiveness; Africa.

JEL classification: 01304 I32 N17.

\section{INTRODUCTION}

Most of the world's poor are rural, depending on agriculture for livelihood; thus the linkage between rural poverty and agriculture is necessarily a close one. Poverty is predominantly rural both in its absolute and relative measure in Africa. In Sub-Saharan Africa, more than $65 \%$ of the population are rural, out of which $56 \%$ depend on agriculture for their for their livelihood. Also, agriculture in the region is largely subsistence and production is concentrated in low-value food crops accounting for more than $70 \%$ of the regions agricultural output. This makes rural poverty transgenerational in its form due to limited asset base, weak or non-existent market linkages and lack of access to financial services. The renewed commitment to agriculture at national and global level intensified in 2009, following the fact that for the first time in history, the number of hungry people in the world surpassed 1 billion. This was largely as a result of the earlier food and financial crises.

The recent comeback by the development cooperation in exploring the dynamics of agriculture and rural growth promotion reveals some signs of a reversal in the long-term neglect of agriculture. Also, considering the rising statistics of poverty with focus on the sector and space where the poor are employed and lives respectively; policy makers have come to realize that poverty reduction in developing countries is achievable only if development efforts are targeted at agriculture.

The MDG set in with a target of halving the number of people living in extreme poverty proportion of people whose income is less than
1US\$ per day and suffering from hunger. Exceptional progress ${ }^{1}$ were made in some developing countries, however, a number of countries fall short and up to 1billion will likely remain destitute by 2015 . For over 30 years on, those living in developing countries depending on agriculture for a living are typically much poorer than those working in other sectors of the economy, which usually represent a significant share of the population. In the words of $[1]^{2}$, effectiveness in addressing poverty and alleviating the standard of living of the World poor requires an adequate knowledge of the economics of agriculture.

Theoretical reviews identify the linkages between agricultural productivity and poverty reduction. Available evidence suggests multiple pathways through which increases in agricultural productivity can reduce poverty; this include real income changes, employment generation, rural non-farm multiplier effect and food prices effects. Likewise, [2] outlines four channels through which agricultural productivity reduces the incidence of poverty, comprising i. direct impact of improved agricultural performance on rural incomes, ii. Impact of cheaper food for both urban and rural poor, iii. Agriculture's contribution to growth and the generation of economic

\footnotetext{
1 The share of undernourished people in the region's population fell from 35\% (1990/92 MDG base) to 32\% (2001/03). Countries like Ghana and probably Gabon have already met MDG goal on undernourishment. Most success stories correlated with agricultural production growth.

${ }_{2}^{2}$ Theodore Schultz 1979 Nobel price acceptance speech "most of the people in the world are poor, so if we knew the economics of being poor we would know much of the economics that really matters. Most of the world's poor people earn their living from agriculture, so if we knew the economics of agriculture we would know much of the economics of being poor"
} 
opportunity in the non-farm sector, and iv. Agriculture's fundamental role in stimulating and sustaining economic transition ${ }^{3}$. Also, [3] posits that labour market expansion, rising farm income and declining food prices are the three key channels that link agricultural growth to poverty. [4] concluded that agricultural productivity growth has a robust and consistent impact on poverty for all productivity measures. However, [5] identified limited initial asset endowment, barriers to technology adoption ${ }^{4}$ and constraints to market access as inhibiting the ability of the poor to participate in the gain from agricultural productivity growth.

The existing empirical literature and theoretical researches addressing the subject matter suggests that agricultural income growth is more effective in reducing poverty than growth in other sectors due to two factor. First, because the incidence of poverty tends to be higher in agricultural and rural populations than elsewhere. Secondly, most of the poor live in rural areas and a large share of them depend on agriculture for a living [6-8]. [7] justified this claim by illustrating empirically that benefits accruable from agricultural growth can be easily obtain if the growth occurred where they are located, implying that the contribution of economic growth to poverty reduction differs across sectors. The underlying reasoning hinges on the assumption that market differentiation, remoteness or political economy consideration makes it difficult to transfer income generated in one geographical location or sector to another. Similarly, [8] opined that the poverty reduction impact of agricultural growth tends to be four times greater than growth in secondary and tertiary sectors. On the other hand, $[9,10]$ identified industrial growth and service sector growth as having the greatest impact of poverty reduction in Asian developing economies. In spite of the vast and growing interest of poverty reducing potential of agriculture development in literature, the Africa region has witnessed limited attention. This present re-examination analyses the conceptual linkages from agricultural productivity to inclusive growth in Africa, and also, an empirical impact of agricultural productivity on rural, urban and dollar poverty in Africa.

\footnotetext{
3 The [2] report posits that countries (and poor people's livelihood) shift away from being primarily agricultural towards a broader base of manufacturing and services.

${ }^{4}$ Agricultural innovation and technological adoption can have both direct and indirect effects on livelihood and productivity improvement of the beneficiaries - the rural agriculture dependent population [11].
}

The remaining part of the study is structured as follows: chapter two addresses the theoretical linkages and association with existing literature on poverty-agricultural productivity nexus. The third chapter outlines the conceptual framework reflecting channels and the processes through which agricultural productivity translates into poverty reduction and inclusiveness. Chapter four of the study addresses the methodology where the relevant empirical model was adopted to validate the thrust of the study. The fifth chapter comprises the discussion of empirical results and relation to extant theories and studies. The last chapter, six, concludes the paper with relevant policy recommendation rising from the empirical results.

\section{LITERATURE REVIEW}

The pioneered theoretical literature opines that as economic progresses, a declining share of agriculture in national employment and GDP becomes inevitable ${ }^{5}[12,13]$. In spite of this paradox, the declining share of agriculture is usually accompanied by rising incomes and reduction in incidence of poverty among agricultural dependent population. An empirical investigation by [2] suggests a close correlation between poverty reduction and agricultural performance. To this end, there are combined national and international effort towards eradication of extreme poverty which is reflected in the initiation of the Millennium Development Goals (MDGs) and the Sustainable Development Goals (SDGs).

The achievement of this goal is highly dependent on global optimization of agricultural productivity. In this article we shall consider the linkages and pathways of agricultural productivity vis-a-vis poverty reduction and inclusive growth in Nigeria.

Schneider and Gugerty [5] studied the linkages between increases in agricultural productivity and poverty reduction. The salient evidence in their work suggests that there are multiple pathways through which increases in agricultural productivity can reduce poverty, including real income changes, employment generation, rural non-farm multiplier effects, and food prices effects. They further posited that barriers to technology adoption, initial asset endowments, and constraints to market access may all inhibit

\footnotetext{
${ }^{5}$ This is largely due to higher income elasticities of demand for non-agricultural goods and services. As people's income increases, the proportion of income spent on manufacturers (non-agricultural goods) rises proportionally.
} 
the ability of the poorest to participate in the gains from agricultural productivity growth. [14] specified two research questions concerning the importance and magnitude of agricultural productivity on poverty alleviation and the relationship among technological innovation, agriculture productivity and poverty. Using an aggregate annual panel data on a sample composed of 32 Sub-Saharan Africa countries from 1990-2011. The study estimated a simultaneous equation model that capture the interrelationship among agriculture productivity, technological innovation and poverty. The findings indicate that agricultural growth contributes significantly to poverty alleviation in SSA. The study results suggest that agricultural growth would lead to a $32 \%$ decrease in poverty: this effect is divided on a direct impact of $0.98 \%$ and an indirect impact via economic growth equal to $0.22 \%$. The study similarly illustrate that $1 \%$ change in technological innovation leads to a decrease in poverty rate by $0.18 \%$.

In the same manner, [15] (Extensions to DFID Report No.7946) looked at the empirical relationships among agricultural productivity growth, poverty reduction, nutritional improvement, inequality and GDP per capita growth in some detail. They found out that the empirical estimates of the relationship between labour productivity in agriculture and poverty reduction appears to be particularly robust. For all the specifications of the model and for all the different samples, labour productivity in agriculture is found to be a powerful and always significant cause of poverty reduction. These results confirm the predominant view in the literature surveyed in [4], that agricultural productivity growth can be expected to have an impact on poverty. [16] provides for the first time a clear quantitative link between agricultural productivity and poverty among rural households in Nepal. Using data from a nationwide Nepal Living Standard Survey 2004, they first estimate household-specific productivity per worker under both Cobb-Douglas and translog production functions. Second, the paper identifies the determinants of productivity. Third, they explore a theoretical link between productivity and poverty using Sen's poverty index and find empirically that productivity growth substantially helps poverty reduction. Finally, the integrated effects of changes in productivity determinants are found to be stronger than the outcomes of sectorial policies taken in isolation. Also in reviewing the relevance of agricultural growth to poverty reduction, [17] sets out the theoretical reasons for expecting agricultural growth to reduce poverty. Several plausible and strong arguments apply - including the creation of jobs on the land, linkages from farming to the rest of the rural economy, and a decline in the real cost of food for the whole economy, but the degree of impact is in all cases qualified by particular circumstances. The article deploys a crosscountry estimation of the links between agricultural yield per unit area and measures of poverty. This produces strong confirmation of the hypothesised linkages. [18], employed a unique, spatially-explicit dataset to study the link between agricultural performance and rural poverty in Madagascar. They showed that, controlling for geographical and physical characteristics, communes that have higher rates of adoption of improved agricultural technologies and, consequently, higher crop yields enjoy lower food prices, higher real wages for unskilled workers, and better welfare indicators.

Nin-Pratt et al. [19], measure and compare agricultural total factor productivity (TFP) growth and its components (efficiency and technical change) in China and India and test the TFP series for the existence of structural breaks relating the evolution of TFP to policy milestones. Their results show that agricultural TFP growth accelerates in China after 1979 and in India after 1974, although China's agricultural sector clearly outperforms India's. The main explanation of these differentials is that agricultural growth in China benefited from more fundamental institutional and policy reforms in agriculture than India. There is some evidence that the transformation of industry in China was also important for agricultural TFP growth. Manufacture growth absorbed labor and reduced employment in agriculture, creating incentives for capital investment and technical change that kept output per worker in agriculture growing at high rates. Fewer changes in agricultural policies and in the dynamics of manufacturing in India resulted in slower growth in agricultural productivity, despite policy changes that accelerated economic growth in recent years.

Matsuyama [20], addressed the role of agricultural productivity in economic development in a two-sector model of endogenous growth in which (a) preferences are non-homothetic and the income elasticity of demand for the agricultural good is less than unitary, and (b) the engine of growth is learning-by-doing in the manufacturing sector. For the closed economy case, the model predicts a positive link between 
agricultural productivity and economic growth, while, for the small open economy case, it predicts a negative link. This suggests that the openness of an economy should be an important factor when planning development strategy and predicting growth performance.

A number of studies considered the subject matter with specific attention to some countries of interest. [21] examined the natural resource status of southern Africa and analyzed the critical linkages between the performance of southern African agriculture and natural resource use patterns. The implication of on-going natural resource use trends on poverty, food insecurity, and environmental degradation are also analyzed. The challenges that must be addressed including, how best to intensify agricultural production, the types of technologies to promote and the imperatives of production efficiency and intra-regional trade were examined. [22], used the experience of India over the past 30 years to address the issue of whether agricultural technical change actually leads to economic diversification and income growth within the rural sector in the context of an open-economy country in which there are crossarea trade and capital flows. The study focused in particular on the rural sector because this is the sector in which linkages between agricultural and nonagricultural sectors are thought to be the strongest.

Testing the impact of deforestation on aggregate agricultural productivity, [23], used an aggregate data from Côte d'Ivoire (the country with the highest annual rate of deforestation in percentage terms, i.e. $6.5 \%$ ), average yield function is estimated which permits a variety of specific hypotheses to be tested. Results indicate that deforestation in the current period contributes positively to yields, and that increases in the cumulative amount of deforested lands cause yields to fall. This aggregate evidence confirms soil scientists' findings that crop yields increase after slash and burn deforestation because of the nutrient content of the ash. Yields decline over time because of the removal of organic matter, erosion, and movement of cropping activity onto marginal lands. Aggregate yields were also found to respond positively to fertilizer applications, but with diminishing marginal productivity. Computed elasticities show that yield response to cumulative deforested land is quite 'elastic'. Other things being equal, a $10 \%$ increase in cumulative deforested land results in a $26.9 \%$ decline in aggregate yields.

Msuya [24] examined the impact of Foreign Direct Investment (FDI) on agricultural productivity and poverty reduction as well as factors that hinder FDI flow to agriculture in Tanzania. Also, the role of FDI in improving an agricultural firm's efficiency in Tanzania and reforms required for more effective investment promotion in agriculture are examined. It is observed that FDI has a positive impact on productivity especially to smallholder farmers who are linked in integrated producer schemes. The study recommends rethinking of the smallholder institutional setup for increasing productivity and FDI flow to the agricultural sector. An important implication of the results is that FDI to Tanzania and specifically to agriculture, has a much more far- reaching economic and social impact than in other sectors.

In the Nigerian context, [25] focused on the growth of the agricultural sector of the Nigerian economy. Factors affecting domestic agricultural production were highlighted using descriptive statistics and regression analysis. The study showed that the overall agricultural production average growth rate was $5.4 \%$ and that GDP growth rate, population growth rate, and the Consumer Price Index were the main factors affecting domestic agricultural production. This study recommended the need to increase percapita productivity through the introduction of improved technology in agricultural production. Also, [26] examined the role of agriculture in poverty reduction in Nigeria between 1980 and 2011. The results from his Augmented DickeyFuller (ADF) unit root test and Error Correction Mechanism showed that per capita agricultural GDP, physical infrastructure per capita and social infrastructure per capita were positively and significantly related to poverty reduction while per capita non-agricultural gross domestic product (GDP) and inflation rate were negatively and insignificantly related to poverty reduction in Nigeria. He recommends among others that government should provide the needed assistance to Nigerian farmers to transform and adopt the use of modern technology so as to stimulate higher productivity in agriculture and reduce the level of poverty in the country.

Imahe and Alabi [27] conducted a basic examination of some determinants of agricultural productivity in Nigeria. The measures of 
productivity considered are agricultural gross domestic production, aggregate index of agricultural production, output of major agricultural commodities (staples) and other output of major agricultural commodities excluding staples, and these constituted the dependent variables in the models specified. The determinant variables (independent) are arable land per capita, average rainfall, fertilizer distribution, value of food imports, agriculture capital expenditure and the loans by commercial banks to agricultural sector. The output of the regression analysis showed that the six selected independent variables contributed significantly to the systematic variation in agricultural productivity and output of major agricultural commodities in the four models specified. The results point out that for the Nigerian agricultural sector to be one of the routes to her prosperity in the new millennium, the governments and the private investors should focus their attention on effective procurement and timely distribution of fertilizers. Nigeria needs to intensify dry land irrigation and revival of river basin farming instead of depending on rain-fed farming; making borrowing by small-scale farmers affordable given their income levels. There is need to discourage excessive importation of food items; pursuing the existing land use decree to create access to farmlands and increasing capital investment on agricultural sector via budgets.

Factors aside from poverty and inclusive growth studied by researchers with respect to agricultural productivity includes Information communication Technology [28], Land reform [29], and Gender differences [30] amongst others. While [5], considered the linkages between increases in agricultural productivity and poverty reduction, in this study we shall extend their work by examining the linkages and pathways through which agricultural productivity leads to poverty reduction and inclusive growth in Nigeria.

\section{CONCEPTUAL FRAMEWORK}

This section illustrates the three key roles agriculture can play in lowering poverty and promoting growth inclusiveness. These channels include: stimulating economic empowerment, creation of markets and fostering sustenance. In addition, the study discusses analytical tools that can help African economies examine these links and determine how agriculture can be leveraged to achieve more inclusiveness in the region.
There is a strong relationship between agricultural stagnation and poverty in subSaharan Africa. Much, though not all, of the solution for poverty alleviation depends on stimulating agricultural growth in Africa. Data collected by the World Bank, the Food and Agricultural Organization of the United Nations (FAO), and the African governments, shows that most of Africa's poor live in rural areas and depend on agriculture for survival. The dependence is both direct in growing food and cash crops, and indirect by working on farms or by trading in agricultural inputs and products. Growth of agriculture, of agricultural production, and of agricultural incomes helps the rural poor, and hence alleviates poverty. It also helps the non-poor, in some cases more than the poor (see Fig. 1).

Agriculture is said to play a key role in promoting inclusive growth. This is achieved primarily by stimulating economic growth, reducing poverty, and creating employment for millions of people in developing economies. However, its potential for future poverty reduction through these transmission mechanisms depends on the extent to which agricultural productivity can be increased where it is most needed.

Productivity growth can catalyze a wide range of direct and indirect effects that mediate the pathways to poverty alleviation [4]. Several studies provide evidence for the poverty reducing potential of agricultural productivity growth in staple crops. In Ethiopia, [31] find that growth in staple crop productivity has greater potential for poverty reduction than any other agricultural or nonagricultural sector in their model. [18] find similar evidence in Madagascar with regard to rice, which is largely non-tradable due to high marketing and transport costs. Finally, [32] find that maize is the single most important crop in most smallholder farm incomes Kenya, Malawi, Zambia, and Mozambique, suggesting that productivity increases could result in poverty alleviation.

It suggests that solving rural poverty through improvement in their source of livelihood entails overcoming many problems, which includes assuring food security, providing employment opportunities for burgeoning urban and rural population, enhancing market expansion, enhancing non-farm sector income, creating better agricultural forward and backward linkages, eliminating transgenerational poverty and maintaining a sustainable natural resource 
base. In the words of [33], over two hundred million people in Sub-Saharan Africa live in extreme poverty and among these are the rural poor in Eastern and Southern Africa where the world's highest concentration of poor people are found. The proportion of rural poor engaging in farming varies geographically and many rural households are still net food buyers [34]. According to [35], $77 \%$ of the poor in SubSaharan Africa are small farm holders - largely women and children. This reflects in [36], which posits that women ${ }^{6}$ grow more than half of the food cultivated around the world today. In subSaharan Africa and the Caribbean, they produce as much as 80 per cent of basic foodstuffs consumed locally. Poor women farmers generally have higher levels of ill health, less secure access to land and lower participation in decision-making in their communities. Hence, enhancing agricultural productivity reduces the burden of poverty of the most vulnerable agricultural dependent rural poor population.

\section{METHODOLOGY}

The study adopts an empirical model based on the linkage established in conceptual analysis. The model suggests a linear relationship of the agricultural determinants of inclusive growth in Africa.

$$
\begin{aligned}
\text { clu }_{i t}=\beta_{0}+\beta_{1} & \text { avpw }_{i t}+\beta_{2} \text { fpi }_{i t}+\beta_{3} c r d t_{i t} \\
& +\beta_{4} g d p k_{i t}+\beta_{5} \text { agre }_{i t}+\beta_{6} \text { inst }_{i t} \\
& +u_{t}
\end{aligned}
$$

Where $\boldsymbol{i c l} \boldsymbol{u}_{i t}$ is a measure of inclusive growth and is been captured using five indicators, namely; unemployment, rural poverty headcount ratio at national poverty lines, urban poverty headcount ratio at national poverty lines, poverty headcount at $\$ 1.90$ a day, income share held by lowest $20 \%$ and poverty headcount at national poverty lines. Hence, $\boldsymbol{i c l u}_{\boldsymbol{i t}}$ is a column vector represented as:

\footnotetext{
${ }^{6}$ Women smallholder farmers face the same constraints as other poor smallholder farmers, such as inadequate access to capital, markets and services. In addition, they gather firewood - a job that can take hours out of every day - collect water, wash clothing, and feed and tend to children. Which makes them more vulnerable and mostly affected poverty.

${ }^{7}$ There might be no substantial progress in poverty reduction and sustainable development unless there is greater investment in women farmers, and unless gender differences are taken into account when planning and implementing programmes.
}

$$
\begin{aligned}
& \left\{\begin{array}{c}
\text { uemp } \\
\text { rpvt }_{i t} \\
\text { upvt }_{i t} \\
\text { pvty }_{i t} \\
\text { pvty }_{n_{i t}}
\end{array}\right\}= \\
& \begin{array}{r}
\beta_{0}+\beta_{1} \text { avpw }_{i t} \\
+ \\
+\beta_{2} \text { fpi }_{i t}+\beta_{3} c r d t_{i t}+\beta_{4} g d p k_{i t} \\
+\beta_{5} \text { agre }_{i t}+\beta_{6} \text { inst }_{i t}+u_{t}(2)
\end{array}
\end{aligned}
$$

Where,

$\boldsymbol{u e m p}_{i t}$ is unemployment, total (\% of total labour force)

$\boldsymbol{r p v t _ { i t }}$ is rural poverty headcount ratio at national poverty lines (\% of rural population)

$\boldsymbol{u p v t _ { i t }}$ is urban poverty headcount ratio at national poverty lines $(\%$ of urban population)

pvty $_{i t}$ is poverty headcount at $\$ 1.90$ a day (2011 PPP) (\% of population)

$\boldsymbol{p v t y} \boldsymbol{n}_{i t}$ is poverty headcount at national poverty lines (\% of population)

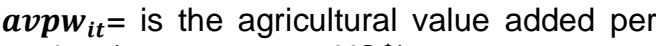
worker (constant 2010 US\$)

$\boldsymbol{f p i}_{i t}=$ food production index (2004$2006=100$ )

$\boldsymbol{c r d t}_{i t}=$ Domestic credit for private sector $(\%$ of GDP)

$\boldsymbol{g} \boldsymbol{d p} \boldsymbol{k}_{\boldsymbol{i t}}=$ GDP per Capita (constant 2010 US\$)

Agre $_{i t}=$ Agricultural raw material exports (\% of merchandise exports)

inst $_{i t}=$ the average measure of four institutional quality indices by the World Bank Governance indicators.

According to [37], improvement in agricultural productivity are important for poverty reduction and has been coined in literature to include: general output per unit of input, farm yield by crop or total output per hectare, and output per worker. In this study, agricultural productivity is captured using agricultural value added per worker and food production index. Also the model is controlled for the quality of domestic institutions provided by World Governance Indicators of [38]. According to [39] debates abounds on the relative importance of determinants of poverty, convincible among these strands adjudged institutions as a critical factor for growth expansion in developing economies [40]. [6] identifies high rates of investment in agricultural research and extension, well-functioning institutions and good governance. The opponents of focus on agriculture, especially in Sub-Saharan Africa argued that previous efforts have achieved little 
results due to civil conflicts and poor institutions [41].

Two main identification strategies are employed to estimate the effect of agricultural productivity on inclusive growth. The first is OLS with a rich set of control variables, on a sample that pools all country-year observations. The second strategy is based on a dynamic panel data model with country fixed effects, and is estimated using the Generalized Method of Moments (GMM). In this model, all predetermined and endogenous variables are instrumented by their appropriate lags, to avoid introducing a spurious correlation between these variables and the error term.

Static panel data models in which the regressors are correlated with the country specific effects are usually estimated using the so-called fixed effects (FE) estimator. The FE estimator requires, however, strict exogeneity of the explanatory variables with respect to the random error term, because country specific time averages are used to transform the regressors and the dependent variable whereby the time averages at time t are correlated with the random shocks at some earlier time, then fixed effects estimator and instrumental variable estimators, based on fixed effects transformation are inconsistent.

Given the growth regression for $N$ countries and $T$ time periods represented as:

$\Delta y_{i, t}=\gamma y_{i, t-1}+\sum_{j=1}^{k} \beta_{j} x_{j, i, t}+\alpha_{t}+u_{i, t}$

Where we indexed time as $t$ and $i$ as countries. Likewise, $\Delta y_{i, t}$ is the average growth rate, $y_{i, t-1}$ represents the logarithm of initial level of GDP per capita, $X_{j, i, t}$ are the $k$ additional regressors and $\alpha_{t}$ is the constant term that may change with time. The errors $u_{i, t}$ are decomposed into time invariant country specific effects, $\mu_{i}$, and random noise, $\varepsilon_{i, t}$, such that:

$$
u_{i, t}=\mu_{i}+\varepsilon_{i, t} .
$$

There are obvious challenges in estimating equation 3. First, the specification shows that the presence of country specific effects such as $\left(\operatorname{var}\left(\mu_{i}\right)>0\right)$ leads to correlation between a regressor $\left(y_{i, t-1}\right)$ and the error term. Secondly, given that some policy variables may be correlated with the random shocks. Due to these inherent challenges, instrumental variable estimation and the static panel data model approach may produce inconsistent results, and we hereby adopt the generalized method of moment approach. The GMM specification can be illustrated as thus:

$$
\begin{aligned}
\Delta y_{i, t}-\Delta y_{i, t-1}= & \gamma\left(y_{i, t-1}-y_{i, t-2}\right) \\
& +\sum_{j=1}^{k^{\prime}} \beta_{j}\left(x_{j, i, t}-x_{j, i, t-1}\right) \\
& +\left(\alpha_{t}-\alpha_{t-1}\right)+\varepsilon_{i, t}-\varepsilon_{i, t-1}
\end{aligned}
$$

As clearly observed in equation 5, regressors may also be correlated with the error term, such that $y_{i, t-1}$ is correlated with $\varepsilon_{i, t-1}$ and $x_{j, i, t}$ may be correlated with $\varepsilon_{i, t-1}$. This challenge is resolved by using lagged observations of the regressors as instruments. Specifically, under the assumption that $x_{j, i, t-2}$ is predetermined, $x_{j, i, t-1}$ is a valid instrument and $x_{j, i t, t-2}$ is valid if $x_{j, i, t}$ is endogenous; a situation valid for our aid and policy instrument. In equation 5, the country specific effects are removed by differencing the data. The data for the empirical investigations were obtained from reputable databases including, World Development Indicators and World Governance Indicators, both of World Bank publications (2015) for the period 1991 to 2015.

\section{DISCUSSION OF RESULTS}

Our estimation procedure began with examining the strength, pattern and direction of collinear relationship among the explanatory variables. The study attempted this by conducting the pairwise correlation matrix in Table 1. The result shows no serious problem of collinear relationship which implies that our model is void of multicollinearity and the specific influence of our regressors is distinguishable. Likewise, the pairwise correlation matrix provides an insight on the likely impact of agricultural productivity on the indicators of inclusive growth. The preliminary evidence shows a negative correlation between unemployment and food production index; similar evidence also obtained between agricultural exports and unemployment. This implies that increased food production index and agricultural exports promote inclusiveness in African economies.

Similarly, the variance inflation factor analysis was adopted to corroborate the results obtained using the pairwise correlation matrix; as the 
former provides a standard rule of examining the extent of collinearity among the exogenous variables. In order to ensure no serious problem of multicollinearity occurs, the variance inflation factor must be less than five and the degree of tolerance greater than 10 percent. An examination of the result presented in Table 2 shows our explanatory variables do not exhibit any near or exact collinear relationship.

Table 3 presents the regression analysis results for the static panel data model using the fixed and random effect specification. The choice of either fixed or random effect specification for the model specified in the study was based on the Hausman test for model reliability. There are basically five sets of results reflecting the five indicators of inclusiveness. Evidences from the result indicates that food production index and per capita income were significant in reducing both rural and urban poverty in Africa. In all category of poverty indicators assessed, food production index has the largest effect on urban poverty while per capita income posed same effect on rural poverty. Also, domestic credit impacts significantly other indicators of inclusiveness except urban poverty. A $1 \%$ increase in domestic credit reduces rural poverty, poverty headcount ratio $\$ 1.90$ a day and poverty headcount at national poverty lines by $6.6 \%$, $8.3 \%$ and $5.8 \%$ respectively. Similarly, a $1 \%$ increase in food production index reduces unemployment by $1.79 \%$, rural poverty by $3.54 \%$, urban poverty by $5.28 \%$, poverty headcount ration at $\$ 1.90$ a day by $8.11 \%$ and poverty headcount at national poverty lines by $4.62 \%$. On the other hand, agricultural raw material exports, though significant but increases poverty incidence in Africa for all categories of poverty indicators. This will not be unconnected to the weak supply response and income inelasticities associated with export of agricultural commodities [42,43]. In addition, the result indicates that institutions in Africa played a minimal role in reducing poverty, as it could not significantly lessen the incidence of poverty below $\$ 1.90$ a day. This results needs to be taken with caution, as $\$ 1.90$ a day underestimates the extent of absolute poverty in African economies. It was apparently revealed that institutions could meaningfully impact only one indicator of poverty-poverty headcount ratio at $\$ 1.90$ a day. This indicates the weak level of institutions in most African economies in ensuring efficient income distribution and inclusiveness in Africa.
Table 4 presents the regression analysis results for dynamic panel data model using the systemGMM approach. This is necessitated to overcome the problem of endogeneity of the income and institution variables in the model, thus making the outcome more preferable to the static approach. Similar to the foregoing analysis, the system GMM specification was attempted for the five models specified which is reflective of the five measures of inclusiveness adopted. The result indicates that agricultural value added per worker contributes significantly to reducing unemployment and rural poverty. This implies that agricultural productivity enhances more significantly the livelihood of rural agricultural dependent population - which forms the bulk of unemployed youths and women. This literally implies that, as the relative contribution of rural household farmers to the overall agricultural output increases, the incidence of poverty in rural agricultural dependent population diminishes. This evidence support the work of [3] which concluded that when the direct and indirect effects of agricultural growth are taken into account, such growth is more poverty reducing than growth in non-agricultural sectors. Similarly, food production index leads to significant reduction in the indicators of poverty level with an exception to rural poverty. This would not be unconnected with the reality that the rural poor largely engage in subsistence farming and more than $70 \%$ of rural agricultural outputs are food crops. This reflects the challenge of food accessibility and affordability among the urban poor. The rising food price raises the proportion of total income spent on food consumption by the non-farm population. In most African countries, an average worker expended a larger proportion of income on food. This continually exacerbate insecurity and raise poverty incidence in the region. Similarly, the result shows that domestic credit to private sector significantly reduces all categories of poverty, with a larger effect on rural poverty than urban poverty.

The result suggests that a $100 \%$ increase in domestic credit reduces unemployment, urban poverty, rural poverty, poverty headcount at $\$ 1.90$ a day and poverty headcount at national poverty lines by $1.73 \%, 2.75 \%, 3.94 \%, 7.48 \%$ and $4.90 \%$ respectively. This implies that availability and accessibility of credit enhances growth inclusiveness in African economies. The importance of credit is further reiterated as domestic credit exerts the largest influence poverty, asides institutions. Furthermore, GDP per capita was only significant in reducing urban 
poverty and poverty headcount at $\$ 1.90$ a day. This result opposed the words of [44] suggesting that growth in per capita (economy-wide) is itself driven by growth in agricultural sector income. Since agriculture is heavily subsistence in Africa, it hence implies that growth in per capita income is generated by other sectors or such agricultural growth does not occur in the space of the poor. This is reflective of the level of income inequality in African economies; national income growth impacts only the livelihood of urban population. It hence suggests the non-shared contribution of the rural agrarian population to national economic output and receives no shared benefits. Finally institutions were found to be a significant factor in reducing rural poverty and national poverty headcounts.

In order to ensure the robustness of our parameter estimates, the study adopted some specification diagnosis tests, these includes the
Arrelano-Bond test for autocorrelation, test of instruments validity and the F-test for the overall significance of our regressors (Akinyemi, Osabuohien, Alege and Ogundipe, 2016). The Arrelano-Bond test is conducted on the differenced residuals in order to purge the unobserved and the perfectly autocorrelated idiosyncratic errors. This is shown as $\operatorname{AR}(1)$ and $A R(2)$ at the lower panel of Table 4, the significance of $A R(1)$, and not necessary $A R(2)$, implies that the successive values of the residuals are not serially correlated. The Sargan and Hansen $\mathrm{J}$ tests assess the over-identifying restriction of whether our instrument vector is exogenous, the test statistics failed to reject the null hypotheses, hence, the validity of our instruments is guaranteed. Finally, the F-statistic, a small sample counterpart of the Wald (ChiSquare) statistics shows that the exogenous variables jointly explained significantly the observed variation in energy security in Africa.

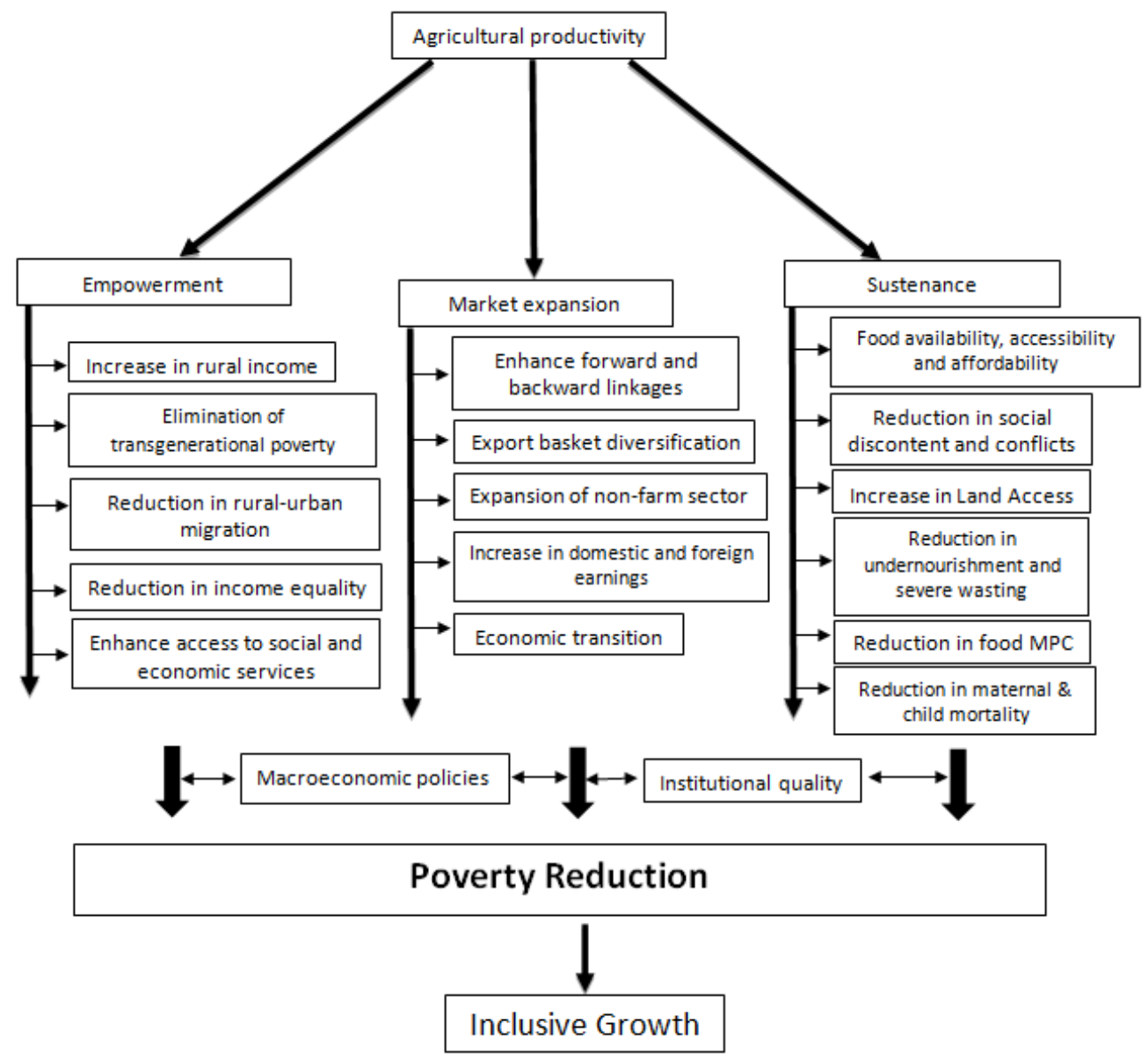

Fig. 1. Agricultural productivity, poverty reduction and inclusive growth framework Source: Authors compilation 
Table 1. Pairwise correlation matrix

\begin{tabular}{llllllll}
\hline Variable & uemp & Avpw & fpi & cdrt & gdpk & agre & inst \\
\hline uemp & 1.0000 & & & & & & \\
avpw & 0.2841 & 1.0000 & & & & \\
fpi & -0.0224 & 0.0519 & 1.0000 & & & \\
crdt & 0.2580 & 0.6999 & 0.0750 & 1.0000 & & \\
gdpk & 0.2604 & 0.5502 & 0.1403 & 0.3021 & 1.0000 & & \\
agre & -0.2728 & -0.2196 & -0.1017 & -0.1680 & -0.2345 & 1.0000 & \\
inst & 0.1277 & 0.3845 & 0.0357 & 0.5585 & 0.2068 & -0.0921 & 1.0000 \\
\hline \multicolumn{7}{c}{ Source: computed using stata 13.0 }
\end{tabular}

Table 2. Variance inflation factor

\begin{tabular}{lll}
\hline Variable & VIF & $\mathbf{1 / V I F}$ \\
\hline Crdt & 2.54 & 0.3938 \\
Avpw & 2.42 & 0.4135 \\
Gdpk & 1.74 & 0.5748 \\
Inst & 1.69 & 0.5907 \\
Agre & 1.08 & 0.9233 \\
Fpi & 1.01 & 0.9905 \\
\hline \multicolumn{2}{l}{}
\end{tabular}

Table 3. Regression analysis result for static panel data model

\begin{tabular}{|c|c|c|c|c|c|}
\hline Variables & $\begin{array}{l}\text { (FE) } \\
\text { Uemp }\end{array}$ & $\begin{array}{l}\text { (FE) } \\
\text { Rpvt }\end{array}$ & $\begin{array}{l}\text { (FE) } \\
\text { Upvt }\end{array}$ & $\begin{array}{l}\text { (RE) } \\
\text { Pvty }\end{array}$ & $\begin{array}{l}\text { (FE) } \\
\text { pvty_n }\end{array}$ \\
\hline Avpw & $\begin{array}{l}-0.000346 \\
(0.000322)\end{array}$ & $\begin{array}{l}0.000392 \\
(0.000432)\end{array}$ & $\begin{array}{l}-0.000530^{*} \\
(0.000296)\end{array}$ & $\begin{array}{l}-0.000626 \\
(0.000594)\end{array}$ & $\begin{array}{l}0.000206 \\
(0.000381)\end{array}$ \\
\hline Fpi & $\begin{array}{l}-0.0179^{* *} \\
(0.00734)\end{array}$ & $\begin{array}{l}-0.0354^{* * *} \\
(0.00931)\end{array}$ & $\begin{array}{l}-0.0528^{* * *} \\
(0.00638)\end{array}$ & $\begin{array}{l}-0.0811^{* * *} \\
(0.0128)\end{array}$ & $\begin{array}{l}-0.0462^{* * *} \\
(0.00820)\end{array}$ \\
\hline Crdt & $\begin{array}{l}0.0347 \\
(0.0223)\end{array}$ & $\begin{array}{l}-0.0660^{* *} \\
(0.0291)\end{array}$ & $\begin{array}{l}-0.0305 \\
(0.0199)\end{array}$ & $\begin{array}{l}-0.0828^{*} \\
(0.0488)\end{array}$ & $\begin{array}{l}-0.0575^{* *} \\
(0.0255)\end{array}$ \\
\hline Gdpk & $\begin{array}{l}-0.000968^{* *} \\
(0.000390)\end{array}$ & $\begin{array}{l}-0.00330^{* * *} \\
(0.000530)\end{array}$ & $\begin{array}{l}-0.000676^{*} \\
(0.000363)\end{array}$ & $\begin{array}{l}-0.00193^{* * *} \\
(0.000621)\end{array}$ & $\begin{array}{l}-0.00322^{* * *} \\
(0.000463)\end{array}$ \\
\hline agre & $\begin{array}{l}-0.0403 \\
(0.0292)\end{array}$ & $\begin{array}{l}0.0580^{*} \\
(0.0305)\end{array}$ & $\begin{array}{l}0.0558^{\star * *} \\
(0.0209)\end{array}$ & $\begin{array}{l}0.0893^{* *} \\
(0.0412)\end{array}$ & $\begin{array}{l}0.0366 \\
(0.0271)\end{array}$ \\
\hline Inst & $\begin{array}{l}3.086^{\star * *} \\
(0.959)\end{array}$ & $\begin{array}{l}-1.588 \\
(1.207)\end{array}$ & $\begin{array}{l}-0.263 \\
(0.828)\end{array}$ & $\begin{array}{l}-4.092^{* *} \\
(1.706)\end{array}$ & $\begin{array}{l}-0.962 \\
(1.064)\end{array}$ \\
\hline Constant & $\begin{array}{l}16.67^{* * *} \\
(1.190)\end{array}$ & $\begin{array}{l}65.50^{* * *} \\
(1.523)\end{array}$ & $\begin{array}{l}38.08^{* * *} \\
(1.044)\end{array}$ & $\begin{array}{l}54.30^{* * *} \\
(3.427)\end{array}$ & $\begin{array}{l}57.91^{* * *} \\
(1.324)\end{array}$ \\
\hline Observations & 632 & 644 & 644 & 637 & 665 \\
\hline R-squared & 0.046 & 0.164 & 0.215 & & 0.212 \\
\hline Number of id & 40 & 41 & 41 & 41 & 42 \\
\hline $\begin{array}{l}\text { Hausman test } \\
\text { Hausman ( } p \text { - } \\
\text { values) }\end{array}$ & & $\begin{array}{l}25.62 \\
0.0003\end{array}$ & & & \\
\hline
\end{tabular}


Table 4. Regression analysis result for dynamic panel data model

\begin{tabular}{|c|c|c|c|c|c|}
\hline Variables & $\begin{array}{l}\text { (SGMM) } \\
\text { Uemp }\end{array}$ & $\begin{array}{l}\text { (SGMM) } \\
\text { Upvt }\end{array}$ & $\begin{array}{l}\text { (SGMM) } \\
\text { rpvt }\end{array}$ & $\begin{array}{l}\text { (SGMM) } \\
\text { Pvty }\end{array}$ & $\begin{array}{l}\text { (SGMM) } \\
\text { pvty_n }\end{array}$ \\
\hline avpw & $\begin{array}{l}-0.000521^{\star \star *} \\
(2.09 e-05)\end{array}$ & $\begin{array}{l}0.000271^{* * *} \\
(1.25 \mathrm{e}-05)\end{array}$ & $\begin{array}{l}-8.09 \mathrm{e}-05^{\star \star \star} \\
(1.99 \mathrm{e}-05)\end{array}$ & $\begin{array}{l}0.000646^{\star \star \star} \\
(9.76 \mathrm{e}-05)\end{array}$ & $\begin{array}{l}0.000185^{\star * *} \\
(1.39 \mathrm{e}-05)\end{array}$ \\
\hline fpi & $\begin{array}{l}-0.0173^{* * \star} \\
(0.000510)\end{array}$ & $\begin{array}{l}-0.000866^{* * *} \\
(5.74 \mathrm{e}-05)\end{array}$ & $\begin{array}{l}0.00120^{* * *} \\
(0.000250)\end{array}$ & $\begin{array}{l}-0.00600^{* \star *} \\
(0.00160)\end{array}$ & $\begin{array}{l}-0.00103^{* * *} \\
(0.000324)\end{array}$ \\
\hline crdt & $\begin{array}{l}-0.0217^{\star \star \star} \\
(0.00290)\end{array}$ & $\begin{array}{l}-0.0275^{\star * \star} \\
(0.000406)\end{array}$ & $\begin{array}{l}-0.0394^{* * \star} \\
(0.00139)\end{array}$ & $\begin{array}{l}-0.0748^{\star * \star} \\
(0.00957)\end{array}$ & $\begin{array}{l}-0.0490^{* \star \star} \\
(0.00149)\end{array}$ \\
\hline gdpk & $\begin{array}{l}0.00116^{\star \star *} \\
(3.23 e-05)\end{array}$ & $\begin{array}{l}-5.87 \mathrm{e}-05^{\star * *} \\
(1.91 \mathrm{e}-06)\end{array}$ & $\begin{array}{l}0.000663^{\star \star \star} \\
(3.41 \mathrm{e}-05)\end{array}$ & $\begin{array}{l}-0.000397^{\star * *} \\
(0.000152)\end{array}$ & $\begin{array}{l}0.000564^{* * *} \\
(1.58 \mathrm{e}-05)\end{array}$ \\
\hline inst & $\begin{array}{l}1.677^{\star \star *} \\
(0.221)\end{array}$ & $\begin{array}{l}0.696^{* * *} \\
(0.0183)\end{array}$ & $\begin{array}{l}-1.677^{* \star \star} \\
(0.132)\end{array}$ & $\begin{array}{l}-1.276^{* * *} \\
(0.143)\end{array}$ & $\begin{array}{l}-1.587^{* \star \star} \\
(0.0836)\end{array}$ \\
\hline I.uemp & $\begin{array}{l}0.732^{\star \star \star} \\
(0.00435)\end{array}$ & & & & \\
\hline l.upvt & & $\begin{array}{l}0.924^{\star * *} \\
(0.00119)\end{array}$ & & & \\
\hline I.rpvt & & & $\begin{array}{l}0.925^{* * *} \\
(0.00110)\end{array}$ & & \\
\hline I.pvty & & & & $\begin{array}{l}0.887^{\star \star \star} \\
(0.00593)\end{array}$ & \\
\hline I.pvty_n & & & & & $\begin{array}{l}0.914^{* * *} \\
(0.00258)\end{array}$ \\
\hline Constant & $\begin{array}{l}4.705^{\star * *} \\
(0.218)\end{array}$ & $\begin{array}{l}3.064^{* * *} \\
(0.0181)\end{array}$ & $\begin{array}{l}2.466^{* * *} \\
(0.0986)\end{array}$ & $\begin{array}{l}5.623^{* * *} \\
(0.585)\end{array}$ & $\begin{array}{l}2.600^{\star * \star} \\
(0.147)\end{array}$ \\
\hline Observations & 684 & 695 & 695 & 688 & 717 \\
\hline Number of id & 43 & 44 & 44 & 44 & 45 \\
\hline F-test (Wald $\subset^{2}$ ) & 66.45 & 7.89 & 54.40 & 84259.22 & 89.943 \\
\hline $\begin{array}{l}\text { F-test ( } p \text { - } \\
\text { values })\end{array}$ & 0.0000 & 0.0000 & 0.0000 & 0.000 & 0.000 \\
\hline Sargan & 0.812 & 0.632 & 0.937 & 0.982 & 0.683 \\
\hline Hansen & 0.915 & 0.791 & 0.321 & 0.938 & 0.879 \\
\hline $\mathrm{AR}(1)$ & 0.041 & 0.002 & 0.011 & 0.072 & 0.217 \\
\hline$A R(2)$ & 0.731 & 0.621 & 0.992 & 0.899 & 0.866 \\
\hline $\begin{array}{l}\text { No. of } \\
\text { instruments }\end{array}$ & 17 & 18 & 17 & 17 & 17 \\
\hline
\end{tabular}

\section{CONCLUSION AND RECOMMENDA- TION}

This study examined the effect of agricultural productivity on poverty reduction and inclusiveness in Africa using the dynamic panel data approach. The System-GMM estimation technique was adopted and preferred to the traditional OLS pooled regression and the static panel approach with the view of resolving the endogeneity problem inherent in the specified model. Specifically, agricultural productivity was captured using agricultural value added per worker and food production index. The former suggests the relative contribution of farmers or agriculture dependent population to national growth while the latter covers the production of food crops that are considered edible and that contain nutrients. It simply suggests the availability of food for sustenance. On the other hand, poverty and inclusiveness was captured using five indicators: rural poverty, urban poverty, dollar poverty, unemployment and national poverty. The conceptual framework of the study identified three main linkages via which agricultural productivity leads to poverty reduction. This include: $i$. income empowerment, ii. Market expansion, and iii. Sustainance enhancement. This implies that developmental efforts focused at enhancing productivity of livelihood and spaces of the rural poor results in increase of rural income, elimination of transgenerational poverty, equitable access to social and economic services. This will also bring 
about enhanced forward and backward agricultural linkages, expansion of non-farm sector income, food affordability, reduction in social discontent and conflicts, reduction in undernourishment and severe waste in adult and children.

Available evidences from the empirical investigation indicates that agricultural value added per worker contributes significantly to reducing unemployment and rural poverty in Africa. Since poverty is firmly entrenched in the rural areas and agriculture constitute the main income source for the 1.4 billion extremely poor people., an enhancement of the productivity of agriculture literarily regresses the incidence of poverty. This is consistent with $[7,3,45]$ but in contrast with [46]. On the other hand, food production index does not yield a significant reduction in rural poverty, though, this was obtained in other indicators of poverty. This result implies that food accessibility and affordability will pose a major threat to the non-farm poor, as larger proportion (if not all) of their income is spent on consumption.

Moreover, GDP per capita was found to significantly reduce urban poverty and dollar poverty. This reflects the height of income inequality and non-inclusiveness in Africa. Since agriculture is predominantly subsistence and growth in one sectors are not easily transferred to another due to market segmentation and geographical remoteness; rural farmers can hardly share in economic growth. In the same manner, domestic credit to private sectors and institutions were significant in reducing all categories of poverty. It implies that development programmes targeted at enhancing agricultural productivity should encompass strategies for accessing credit in order to boost the asset base of rural farmer for a large scale commercial production. Also, appropriate macroeconomic policies and institutional framework quality needs to be put in place in order to boost provision of social services, equitable land and credit access.

\section{COMPETING INTERESTS}

Authors have declared that no competing interests exist.

\section{REFERENCES}

1. Schultz TW. Lecture to the memory of Alfred Nobel; 1979.
Available:http://www.nobel.se/economics/l aureates/1979/Schultz-lecture.html (Dec. 8, 1979)

2. DFID. Agriculture, growth and poverty reduction; 2004.

Available:http://www.dfid.gov.uk/Document s/publications/agri-poverty-reduction.pdf

3. Bresciani $F$, Valdés A. Beyond food production: The role of agriculture in poverty reduction. FAO, Rome; 2007.

4. Thirtle C, Lin L, Piesse J. The impact of research-led agricultural productivity growth on poverty reduction in Africa, Asia and Latin America. World Development. 2003;31(12):1959-1975.

5. Schneider K, Gugerty MK. Agricultural productivity and poverty reduction: Linkages and pathways the evans school review. 2011;1(1).

DOI: http://dx.doi.org/10.7152/12259

6. Cervantes-Godoy D, Dewbre J. Economic importance of agriculture for poverty reduction. OECD Food, Agriculture and Fisheries Working Papers, No. 23, OECD Publishing; 2010.

7. Christiaensen L, Demery L. Down to earth agriculture and poverty reduction in Africa, The World Bank Group; 2007.

8. Ravallion M, Chen S. China's (Uneven) progress against poverty. Journal of Development Economics; 2007.

9. Warr $P$, Wang W. Inequality and economic growth in Taiwan, in: G. Ranis and R. Hu, Editors, The Political Economy of Development in Taiwan: Essays in Memory of John CH Fei, Edward Elgar. 1999;133-165.

10. Warr P. Poverty reduction and sectoral growth: Evidence from Southeast Asia, Paper presented at the WIDER Development Conference on Growth and Poverty, Helsinki; 2001.

11. Ogunniyi A, Olagunju KO, Ogundipe AA. Impact of Agricultural Innovation on Improved Livelihood and Productivity Outcomes among Smallholder Farmers in Rural Nigeria; 2016.

SSRN: 2847537

12. Lewis A. The theory of economic growth, R.D. Irwin. Homewood, Illinois; 1955.

13. Byerlee D, de Janvry A, Sadoulet E. Agriculture for development: Toward a new paradigm. Annual Review of Resource Economics. 2009;1.

14. Dhrifi A. Agricultural productivity and poverty alleviation: What role for technological innovation. Journal of 
Economic and Social Studies. 2014;4(1): 131-149.

15. Lin L, McKenzie V, Piesse J, Thirtle C. Agricultural productivity and poverty in developing countries. Extensions to DFID Report No. 7946.

16. Devkota S, Upadyay M. Agricultural productivity and poverty reduction in Nepal. Review of Developmental Economics. 2013;17(4):732-746.

17. Lrz X, Lin L, Thirtle $\mathrm{C}$, Wiggins $\mathrm{S}$. Agricultural productivity growth and poverty alleviation. Development Policy Review. 2001;19(4):449-466.

18. Minten B, Barrett CB. Agricultural technology, productivity and poverty in Madagascar. World Development. 2008; 36(5):797-822.

19. Nin-Pratt A, Yu B, Fan S. Comparisons of agricultural productivity growth in China and India. Journal of Productivity Analysis. 2010;33(3):209-223.

20. Matsuyama K. Agricultural productivity, comparative advantage and economic growth. Journal of Economic Theory. 1992;58(2):317-334.

21. Abalu G, Hassan R. Agricultural productivity and natural resource use in southern Africa. Food Policy. 1998;23(6): 477-490.

22. Foster AD, Rosenzweig MR. Agricultural productivity growth, rural economic diversity and economic reforms: India, 1970-2000. Economic Development and Cultural Change. 2004;52(3):509-542.

23. Ehui SK, Hertel TW. Testing the impact of deforestation on aggregate agricultural productivity. Agriculture, Ecosystem and Environment. 1992;38(3):205-218.

24. Msuya E. The impact of Foreign direct investment on agricultural productivity and poverty reduction in Tanzania. MPRA Paper, Kyoto University; 2007.

25. Muhammad-Lawal A, Atte OA. An analysis of agricultural production in Nigeria. African Journal of General Agriculture. 2006;2(1).

26. Oni LB. An assessment of agriculture and poverty reduction nexus in Nigeria. Journal of African Macroeconomic Review. 2014; $4(1)$. ISSN: 2220-945X

27. Imahe OJ, Alabi RA. The determinants of agricultural productivity in Nigeria. Journal: Food, Agriculture and Environment (JFAE). 2005;3(2):269-274.

ISSN: 1459-0263
28. Lio M, Liu M. ICT and agricultural productivity: Evidence from cross-country data. Agricultural Economics. 2006;34:22228.

29. Ghatak M, Roy S. Land reform and agricultural productivity in India: A review of the evidence. Oxford Review of Economic Policy. 2007;23(2):251-269.

30. Quisumbing AR. Gender differences in agricultural productivity; 1995. ideas.repec.org

31. Diao X, Pratt A. Growth options and poverty reduction in Ethiopia - an economy-wide model analysis. Food Policy. 2007;32(2):205-228.

DOI: 10.1016/j.foodpol.2006.05.005

32. Jayne TS, Mason N, Myers R, Ferris J, Beaver M, Lenski N, et al. Patterns and trends in food staples markets in Eastern and Southern Africa: Toward the Identification of Priority Investments and Strategies for Developing Markets and Promoting Smallholder Productivity Growth (International Development Working Paper). East Lansing, Michigan: Michigan State University; 2010.

Available:http://ageconsearch.umn.edu/bits tream/62148/2/idwp104.pdf

33. Otieno ZA. Agricultural growth, rural poverty and hunger in Africa. African Association of Agricultural Economists (AAAE). No 521792007 Second International Conference, August 20-22, 2007, Accra, Ghana; 2007.

Available:Econpapers.repec.org/paper/ags aaae07/52179.htm

34. Irz X, Lin Thirtle C, Wiggins S. Agricultural productivity growth and poverty alleviation. Development Policy Review. 2001;19(4): 449-466.

DOI: $10.1111 / 1467-7679.00144$

35. Cox A, Farrington J, Gilling J. Reaching the poor? Developing a poverty screen for agricultural research proposals (ODI Working Paper 112) London: Overseas Development Institute; 1998.

Available:http://www.odi.org.uk/ resources/download/2050.pdf

36. IFAD Annual Report 2009. Enabling Poor Rural People to Overcome Poverty. Available:https://www.ifad.org/documents/1 0180/11d69003-aec3-46c3-a7cc1f31331c74c1

37. Mellor J. Faster, more equitable growth the relation between growth in agriculture and poverty reduction agricultural policy development project (Research Report No. 
4). Washington, D.C.: United States Agency for International Development; 1999.

Available:http://www.abtassociates.com/re ports/19998977199472.pdf

38. WDI. World Bank Database; 2015.

39. World Bank. The growth report: Strategies for sustained growth and inclusive; 2008a.

40. World Bank. World Development Report: Agriculture for Development, The World Bank Group; 2008b.

41. Gollin D. Agricultural productivity and economic growth; 2009.

Available:http://sites.google.com/site/dougl asgollin/doug-gollin/research

42. Ogundipe AA. Commodity price volatility, business cycles and economic growth in selected African Countries. An unpublished
Ph.D Thesis, Covenant University, Ota, Nigeria; 2016.

43. Cervantes-Godoy D, Brooks J. Smallholder adjustment in middle-income countries: Issues and policy responses. OECD Food, Agriculture and Fisheries Working Papers, No. 12, OECD, Paris; 2008.

44. Irz $X$, Tiffin $R$. Is agriculture the engine of growth?, Agricultural Economics Journal. 2006;35(1):79-89.

45. Montalvo J, Ravallion M. the pattern of growth and poverty reduction in China, Policy Research Working Paper 5 069, The World Bank; 2009.

46. Ravallion M, Datt G. Why has economic growth been more pro-poor in some states of india than others? Journal of Development Economics. 2002;65:381400.

(c) 2017 Ogundipe et al.; This is an Open Access article distributed under the terms of the Creative Commons Attribution License (http://creativecommons.org/licenses/by/4.0), which permits unrestricted use, distribution, and reproduction in any medium, provided the original work is properly cited.

Peer-review history:

The peer review history for this paper can be accessed here: http://sciencedomain.org/review-history/19773 